\title{
Bagasse Fly Ash as an Effective Adsorbent: Evaluation of Adsorptive Characteristics for 4-Nitroaniline Removal
}

\author{
Praveen Kumar D. $G^{1} \mid$ Kalleshappa C.M ${ }^{2}$ | Amarnath P.C ${ }^{3} \mid$ Shashikala K. J4 \\ 1,2,3,4 Department of Chemical Enginering and Research Center, Bapuji Institute of Engineering and Technology, \\ Davanagere, Karnataka, India,
}

To Cite this Article

Praveen Kumar D. G., Kalleshappa C.M., Amarnath P.C \& Shashikala K. J. Bagasse Fly Ash as an Effective Adsorbent: Evaluation of Adsorptive Characteristics for 4-Nitroaniline Removal. International Journal for Modern Trends in Science and Technology 7, 155-161 (2021).

Article Info

Received on 18-April-2021, Revised on 11-May-2021, Accepted on 19-May-2021, Published on 22-May-2021.

\section{ABSTRACT}

In the present study we explored the adsorptive characteristics of 4-nitroaniline from synthetic aqueous solution onto bagasse fly ash (BFA). Batch experiments were carried out to determine the influence of parameters like initial $\mathrm{pH}(\mathrm{pHo})$, adsorbent dose $(\mathrm{m})$, contact time $(\mathrm{t})$ and initial concentration $\left(\mathrm{C}_{0}\right)$ on the removal of 4-nitroaniline. The maximum removal of 4-nitroaniline was determined to be $98 \%$ at lower concentrations $(50 \mathrm{mg} / \mathrm{L})$ and $41 \%$ at higher concentrations $(300 \mathrm{mg} / \mathrm{L})$, using a BFA dosage of $10 \mathrm{~g} / \mathrm{L}$ at $303 \mathrm{~K}$. Kinetic study of 4-nitroaniline removal by BFA was well represented by pseudo second-order kinetic model. The 4-nitroaniline desorption from 4-nitroaniline loaded BFA shows that only 27\% and 36\% of 4-nitroaniline could be recovered using ethyl alcohol and acetone respectively.

KEYWORDS:4-nitroaniline; Bagasse fly ash; Adsorption kinetics.

\section{INTRODUCTION}

An organic chemical compound 4-nitroaniline is bright yellow in colour, having 138.12 molecular weight, $1.424\left(20 / 4^{\circ} \mathrm{C}\right)$ density, pKa of 1.00 and formula $\mathrm{C}_{6} \mathrm{H}_{6} \mathrm{~N}_{2} \mathrm{O}_{2}[1]$. This organic chemical is commonly used as an intermediate in the synthesis of varieties of dyes, pesticides, gasoline, poultry medicine pharmaceuticals and antioxidants. Because of 4-nitroaniline toxicity, mutagenicity and carcinogenicity towards different experimental model organisms and stability, it is classified as a hazardous substance. Its presence in very small amount in water can cause a long-term damage to the health of human and aquatic environment [2, 3, and 4]. Ministry of Environmental Protection of China in 1989, officially Black Listed 4-nitroaniline because of its huge threat to environment and restricted its disposal limit less than $1.0 \mathrm{mg} / \mathrm{L}[1,5]$. Many developing and developed nations have enlisted4-nitroaniline as priority pollutant and imposed restriction on its production, usage and disposal [6]. Because of these reasons the proper treatment and disposal of 4-nitroaniline containing waste water is an important environmental concern. Currently, many methods are available to treat 4-nitroaniline containing wastewater by photo-catalysis $[7,8]$, biodegradation $[2,9]$, advanced oxidation $[6,10]$ and adsorption $[10,11$, $12,13,14$, and15]. Among the available technologies, adsorption has been proven to be effective method in treating 4-niroaniline from various water bodies. Many adsorbents like carbon fibre [11], carbon nanotube [14], activated polymeric adsorbents [12, 13], etc., have been 
investigated and utilized to remove 4-nitroaniline.Therefore, new cost effective technologies such as adsorption is used for the removal of 4-nitroaniline becomes crucial because of its simple design, cost effectiveness, ease of operation and simple adsorbent regeneration [13].

In the present study we have used a low cost adsorbent Bagasse fly ash (BFA), excepting its proper collection and transportation to the usage point. Basically BFA is collected downstream to the boilers/furnaces, where particulate collection equipment is attached, using bagasse as the fuel. Because of its excellent adsorption characteristics, BFA has been used by several investigators $[16,17$, 18 , and 19] as an adsorbent for the removal of organics, dyes, phenols, etc.

The adsorption characteristics of 4-nitroaniline from synthetic aqueous solutions onto BFA are reported in the present paper by varying different parameters in a batch study. The effect of initial $\mathrm{pH}$ of the solution, adsorbent dose, initial 4-nitroaniline concentration and contact time on the adsorption of 4-nitroaniline onto BFA have been investigated. Adsorbent characterization, kinetic study of 4-nitroaniline adsorption onto bagasse fly ash, the experimental analysis of data using various kinetic models and desorption study for the possible regeneration of the bagasse fly ash have been reported.

\section{MATERIALS AND METHODS}

\subsection{Adsorbent and its Characterization}

Adsorbent Bagasse fly ash (BFA) is obtained from M/S Davangere Sugar Company Limited, Kukkawada, Karnataka, India. The adsorbent was initially washed with $70^{\circ} \mathrm{C}$ hot water, dried and required particle size $(-1000$ and +180$)$ were obtained by sieving using IS sieves (IS 437-1979) and use for the adsorption studies. Using the standard methods the physico-chemical characteristics, proximate analysis, Bulk density were determined. FESEM micrographs were obtained using scanning electron microscope (MIRA3 TESCAN, USA). BET surface area was obtained from Bellsorp II, Japan instrument.

\subsection{Adsorbate}

The 4-nitroaniline was procured from S.D. Fine chemical Limited, Mumbai, India, was used as adsorbate. $1000 \mathrm{mg} / \mathrm{L}$ of stock solution was prepared initially, then the required concentration of 4-nitroaniline was prepared using stock solution with proper dilution using distilled water as and when required.

\subsection{Analytical Measurement}

4-nitroaniline concentration was determined using UV/VIS spectrophotometer (Perkin Elmer lambda 35, Schimadzu, Japan), by finding out the characteristic maximum absorbance wavelength. The absorbance of standard solution at known concentration was used to plot a calibration curve of absorbance versus wavelength and the maximum absorbance $\left(\lambda_{\max }\right)$ for 4 -nitroaniline was found to be $381 \mathrm{~nm}$. Unknown concentration of 4-nitroaniline solution was determined using linear portion of this curve.

\subsection{Batch Study}

Batch mode experiments were conducted to study the effect of various parameters like adsorbent dose $(\mathrm{m})$, initial $\mathrm{pH}\left(\mathrm{pH}_{0}\right)$, initial concentration $\left(\mathrm{C}_{\mathrm{o}}\right)$ contact time (t) and temperature (T) on the adsorptive removal of 4-nitroaniline by bagasse fly ash. For performing an experimental run, $250 \mathrm{ml}$ stoppered conical flask containing $100 \mathrm{ml}$ of 4-nitroaniline solution with known concentration $\left(\mathrm{C}_{0}\right), \mathrm{pH}_{0}$ and adsorbent dose $(\mathrm{m})$ were agitated at $303 \pm 1 \mathrm{~K}$ in a temperature controlled orbital shaker (Remi- CIS24 Plus, Mumbai) at a constant speed of $150 \mathrm{rpm}$. The effect of contact time $(t=0-3 \mathrm{~h})$ and the effect of different initial concentration over a range of $\mathrm{C}_{\mathrm{o}}=50-300 \mathrm{mg} / \mathrm{L}$ for 4-nitroaniline was studied. Samples were withdrawn from the shaker after appropriate time. These samples were filtered and analysed for the residual 4-nitroaniline concentrations. Effect of $\mathrm{pH}_{0}$ on 4-nitroaniline removal was studied over a $\mathrm{pH}_{0}$ range of 2-12. $\mathrm{pH}_{0}$ was adjusted by addition of $0.1 \mathrm{~N} \mathrm{H}_{2} \mathrm{SO}_{4}$ or $\mathrm{NaOH}$. The optimum dosage $(\mathrm{m})$ was found by contacting different amounts of bagasse fly ash with $50 \mathrm{mg} / \mathrm{L}$ 4-nitroailnie solution till equilibrium was attained. The percentage removal of adsorbate and the equilibrium adsorption uptake in solid phase, qe $(\mathrm{mg} / \mathrm{g})$, were calculated as follows:

Percent Removal $=100 \frac{\left(\mathrm{C}_{0}-\mathrm{C}_{\mathrm{e}}\right)}{\mathrm{C}_{\mathrm{o}}}$

$\mathrm{q}_{\mathrm{e}}=\frac{\left(\mathrm{C}_{\mathrm{o}}+\mathrm{C}_{\mathrm{e}}\right) \mathrm{V}}{\mathrm{w}}$

Where, $\mathrm{q}_{\mathrm{e}}$ is equilibrium amount of adsorbate adsorbed $(\mathrm{mg} / \mathrm{g}), \mathrm{C}_{0}$ is initial concentration of adsorbate in aqueous solution $(\mathrm{mg} / \mathrm{L}), \mathrm{C}_{\mathrm{e}}$ equilibrium concentration $(\mathrm{mg} / \mathrm{L}), \mathrm{V}$ is volume of aqueous solution (L) and $\mathrm{W}$ is the weight of adsorbent (g).

\subsection{Desorption Studies}

Solvent method was performed for desorption studies. 4-nitroaniline concentration $\left(\mathrm{C}_{0}=50\right.$ 
$\mathrm{mg} / \mathrm{L}$ ) loaded adsorbent $(1 \mathrm{~g})$ was agitated in a series of $250 \mathrm{ml}$ conical flasks containing $100 \mathrm{ml}$ of aqueous solution,each $0.1 \mathrm{~N}$ of Acetic Acid, Sulphuric Acid, Nitric Acid, Hydrochloric Acid, Sodium Hydroxide were used. Ethyl Alcohol, Acetone and Distilled Water were also used for desorption at $303 \mathrm{~K}, 150 \mathrm{rpm}$ for $24 \mathrm{~h}$ in the orbital shaker [20].

\section{RESULTS AND DISCUSSION}

\subsection{Adsorbent Characterization}

The physico-chemical properties of BFA like, bulk density, BET surface area, moisture content, volatile matter, ash content, and fixed carbon were found to be $145.23 \mathrm{~kg} / \mathrm{m}^{3}, 215.82 \mathrm{~m}^{2} / \mathrm{g}, 1.29 \%$, $14.16 \%, 26.23 \%$, and $58.32 \%$, respectively [16]. The SEM micrographs as given in Figure. 1(a) shows that the BFA has fibrous structure having large pore size with strands in each fibre. SEM at 100X magnification does not show any difference in the texture of the blank and 4-nitroaniline loaded BFA. It only shows that the BFA is crystalline in nature and with varying particle size. Blank BFA shows pore structure with pores of varying sizes. Numbers of pores observed in the loaded BFA are less as compared to that in blank BFA.

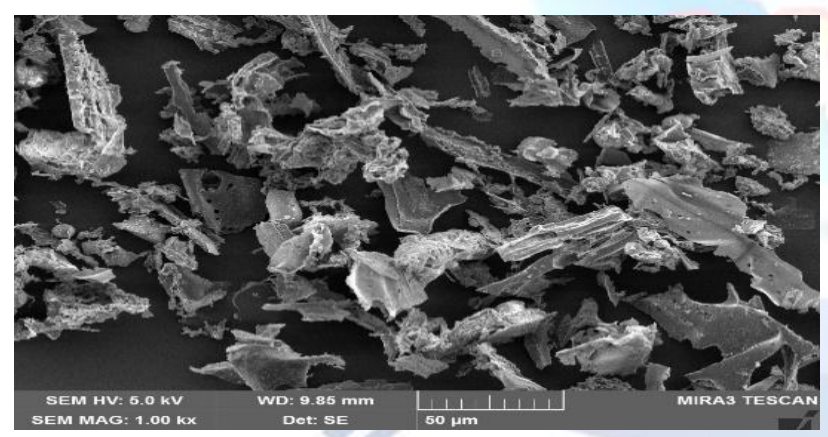

(a)

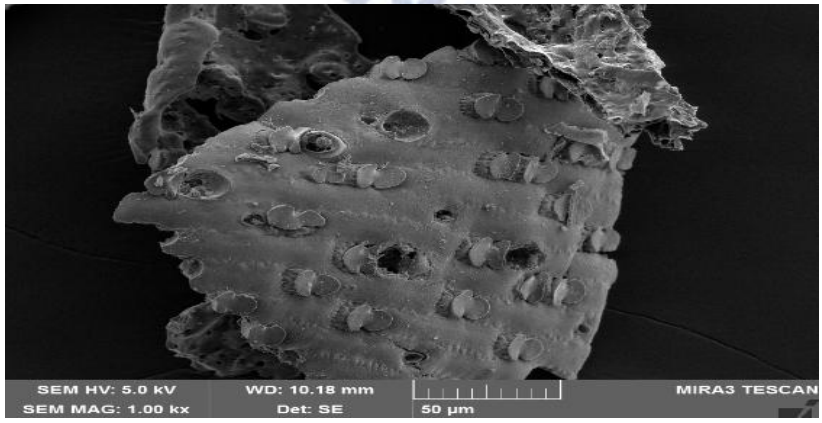

(b)

Figure 1: SEM of (a) Blank and (b) 4-Nitroaniline Loaded Bagasse Fly Ash.

\subsection{Effect of Initial $\mathrm{pH}$ ( $\mathrm{pHo}$ )}

The effect of $\mathrm{pH}_{0}$ was studied with 4-nitroaniline concentration $\mathrm{C}_{0}=50 \mathrm{mg} / \mathrm{L} ; \mathrm{T}=303 \mathrm{~K} ; \mathrm{t}=3 \mathrm{~h}$; and $\mathrm{m}=10 \mathrm{~g} / \mathrm{L}$. The effect of $\mathrm{pH}_{0}$ range of $2-12$ on the 4-nitroaniline removal by BFA is shown in Figure 2. Equilibrium was observed to have been attained within a time of $t=3 \mathrm{~h}$. After which the absorbance of the solution at $\lambda_{\max } 381 \mathrm{~nm}$ was determined. A maximum adsorption of $98 \%$ 4-nitroaniline was observed to occur at the natural $\mathrm{pH}_{0}$. However, as the $\mathrm{pH}_{0}$ increases $\left(\mathrm{pH}_{0}>6.5\right)$, the adsorption decreases with a minimum 4-nitroaniline removal of $95 \%$. The maximum adsorption $98 \%$ was observed at natural pH 6.5. Since 6.5 is the natural $\mathrm{pH}$ of the solution, further experiments were carried out at natural $\mathrm{pH}$.

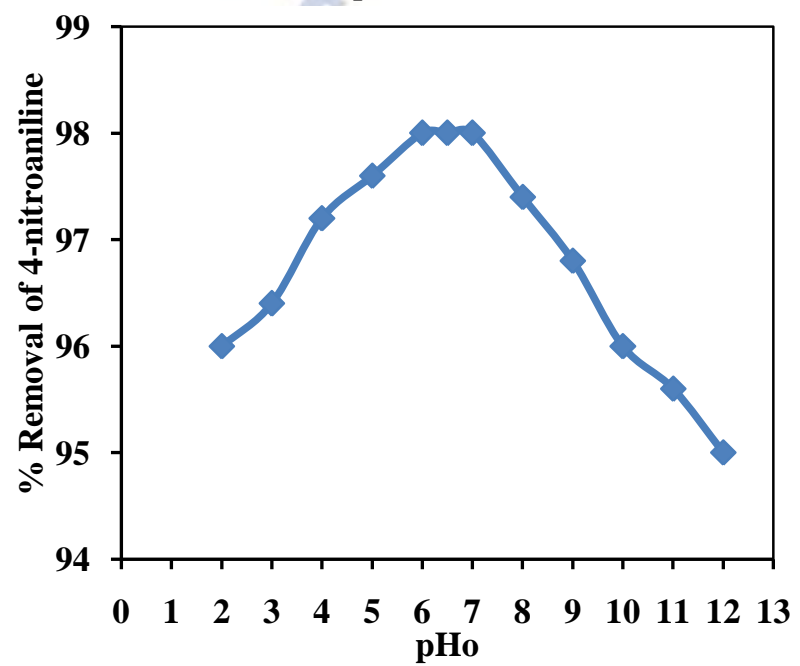

Figure 2: Effect of Initial $\mathrm{pH}$ on 4-nitroaniline Removal $\left(\mathrm{m}=10 \mathrm{~g} / \mathrm{L}, \mathrm{t}=3 \mathrm{~h}, \mathrm{C}_{0}=50 \mathrm{mg} / \mathrm{L}, \mathrm{T}=303\right.$ $\mathrm{K})$.

\subsection{Effect of Adsorbent Dosage (m)}

The adsorbent dose $(\mathrm{m})$ effect on the removal of 4-nitroaniline by BFA at $\mathrm{C}_{0}=50 \mathrm{mg} / \mathrm{L}$ is shown in Figure 3. 4-nitroaniline removal gradually increases up to $\mathrm{m} \leq 10 \mathrm{~g} / \mathrm{L}$, and then it remains almost constant for $\mathrm{m} \geq 10 \mathrm{~g} / \mathrm{L}$. The surface of adsorbent becomes saturated for, $\mathrm{m} \leq 10 \mathrm{~g} / \mathrm{L}$ adsorbates, and the residual concentration in the solution is large. An increase in adsorption with an increase in $\mathrm{m}$ for, $\mathrm{m} \leq 10 \mathrm{~g} / \mathrm{L}$ can be attributed to greater surface area and availability of more adsorption sites. However, for, $\mathrm{m} \geq 10 \mathrm{~g} / \mathrm{L}$, the surface 4-nitroaniline concentrations come to saturation limit with each other and the incremental removal becomes very low. Thus, optimum $\mathrm{m}$ was found to be $10 \mathrm{~g} / \mathrm{L}$. 


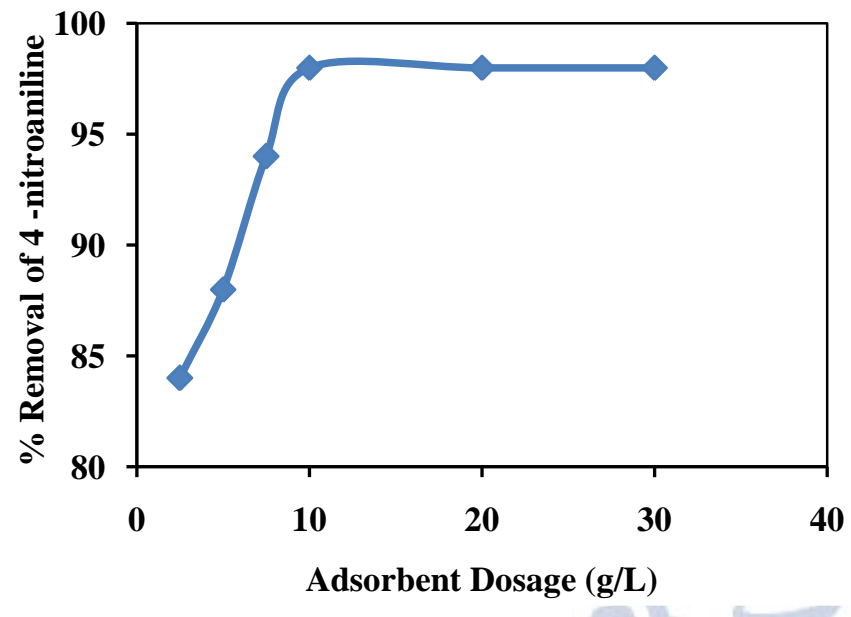

Figure 3: Effect of Adsorbent Dosage on

4-nitroaniline Removal $\left(\mathrm{C}_{\mathrm{o}}=50 \mathrm{mg} / \mathrm{L}, \mathrm{pHo}=6.5, \mathrm{t}\right.$ $=3 \mathrm{~h}, \mathrm{~T}=303 \mathrm{~K}$ )

\subsection{Effect of Initial Concentration}

The effect of initial concentration $\left(\mathrm{C}_{\mathrm{o}}\right)$ on adsorption of 4-nitroaniline on BFA is shown in Figure 4. The removal of 4-nitroaniline was found to decrease as the concentration increased from 50 to $300 \mathrm{mg} / \mathrm{L}$. When $\mathrm{C}_{0}$ was increased, driving force for adsorption increased which further increased adsorption rates and decrease in resistance was also observed. [21, 22].

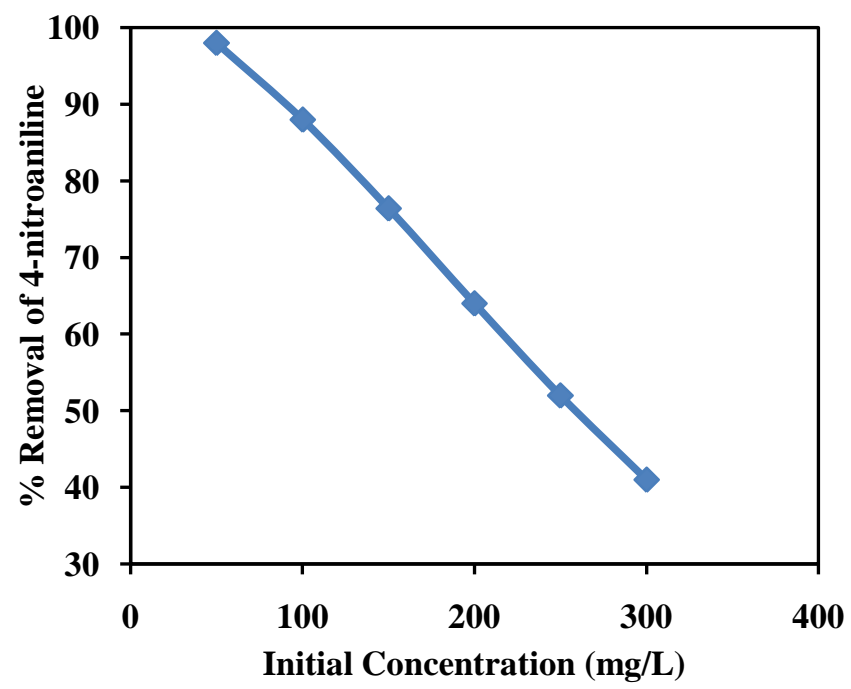

Figure 4: Effect of Initial Concentration on 4-nitroaniline Removal $(\mathrm{m}=10 \mathrm{~g} / \mathrm{L}, \mathrm{pHo}=6.5, \mathrm{~T}=$ $303 \mathrm{~K}$ )

\subsection{Effect of Contact Time}

The time of contact ( $\mathrm{t}$ ) of adsorbate with adsorbents is an important factor for the sorption process. In the beginning the movement of the adsorbate onto surface of BFA is very vigorous and attains an equilibrium condition quickly. At the time of physical adsorption, adsorbate get attached to solid within a small time. At the time of chemical adsorption, equilibrium attainmentbetween adsorbate and adsorbent needs morecontact time [23]. The effect of this factor for removal of 4-nitroaniline $\left(\mathrm{C}_{0}=50-300 \mathrm{mg} / \mathrm{L}, \mathrm{m}=10 \mathrm{~g} / \mathrm{L}\right)$ by $\mathrm{BFA}$, at $\mathrm{T}=303 \mathrm{~K}$, and $\mathrm{pH}_{0}=6.5$ for 4-nitroaniline is shown in Figure 5. The figures show rapid adsorption of 4-nitroaniline during first 15 minutes, and later, the rate gradually decreased. For BFA-4-nitroaniline system about $70 \%$ of adsorption in aqueous solution with $\mathrm{C}_{0}=50 \mathrm{mg} / \mathrm{L}$ was observed during the first minute. After one minute the adsorption was low. The residual concentration of 4-nitroaniline was $4 \%$ at 1 hour, $2 \%$ at 3 hour and $1.9 \%$ at 6 hour. The variation in 4-nitroaniline removal at 3 hour and 6 hour was less than $0.1 \%$.

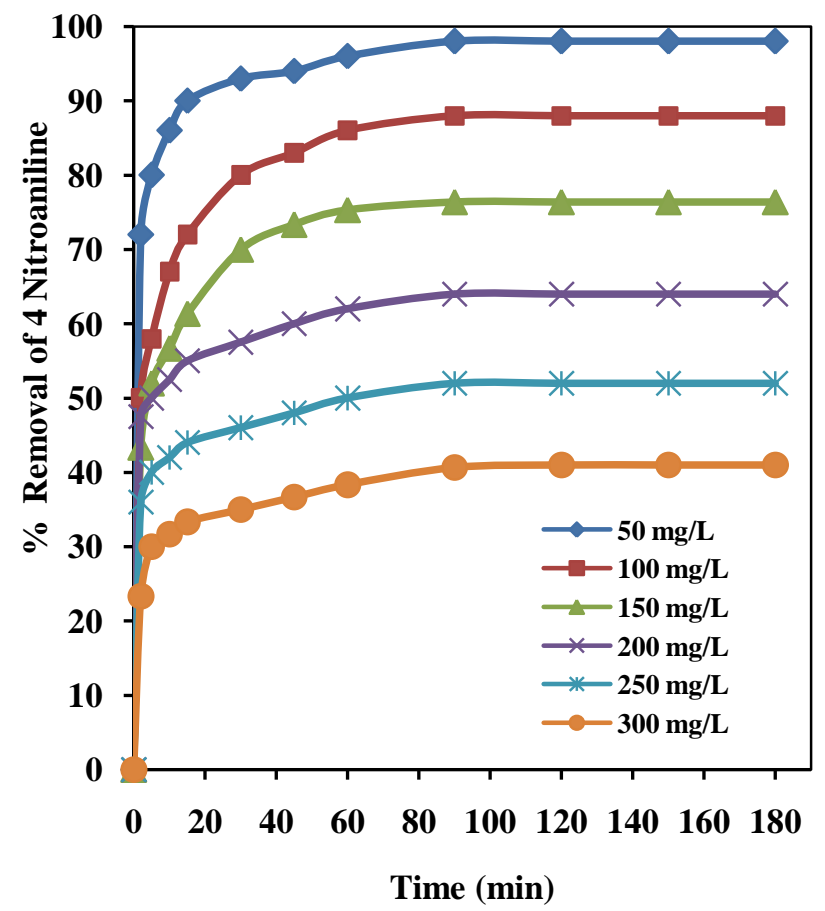

Figure 5: Effect of Contact Time on the 4-nitroaniline Removal by $\operatorname{BFA}\left(\mathrm{m}=10 \mathrm{~g} / \mathrm{L}, \mathrm{pH}_{\mathrm{o}}=\right.$ 6.5, $\mathrm{T}=303 \mathrm{~K}$

\subsection{Effect of Temperature}

The effect of temperature in the range 293-323 K for $\mathrm{C}_{0}=50-300 \mathrm{mg} / \mathrm{L}$ on the adsorption of 4-nitroaniline by BFA was shown in Figure 6. It was observed the increase in adsorption as the temperature was increased. Sorption process liberates heat making an exothermic condition and higher temperature decreases adsorption levels. The higher adsorptive levels of BFA is due to the diffusion process which becomes the rate limiting step and absorbs heat from the solution at elevated temperature. The capacity of adsorption raises with mobility of the 4-nitroaniline due to 
increasedtemperature. For chemical adsorption equilibrium condition shows the maximum adsorption at higher temperatures. The various components of the solution interact in many ways. Allinteractions on the surface are basedon different mechanisms. Physical, chemical properties, pore distribution, shape and size of pores of adsorbent and molecular size play a prominent role in the adsorption.

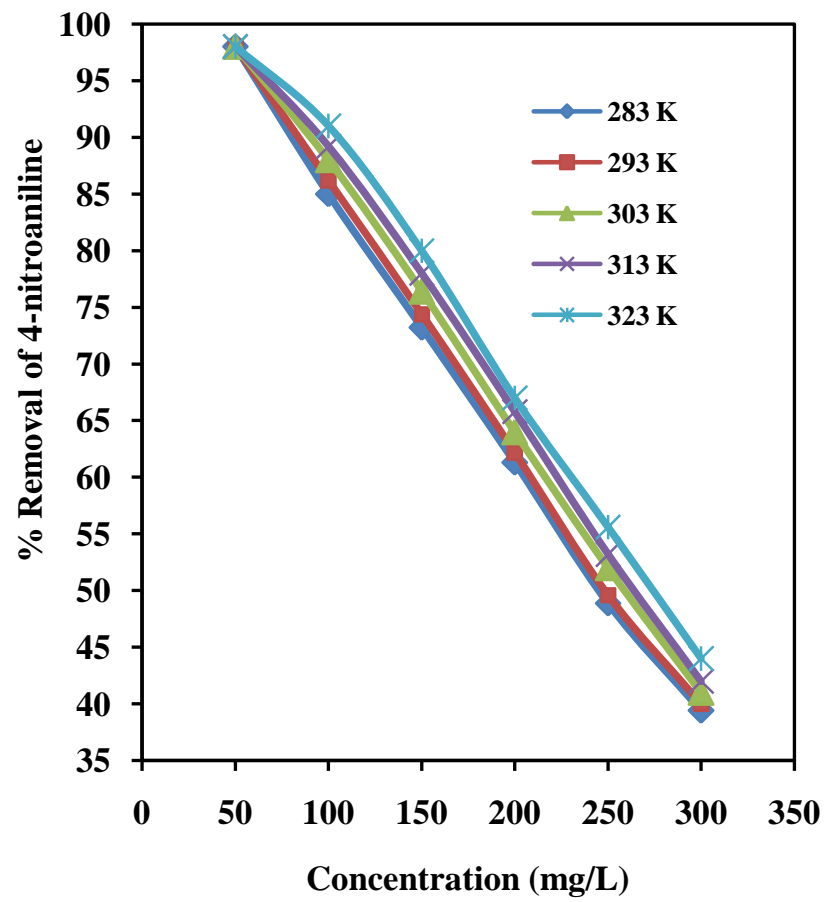

Figure 6: Effect of Temperatures on 4-nitroaniline Removal by BFA ( $\mathrm{m}=10 \mathrm{~g} / \mathrm{L}$, $\mathrm{C}_{0}=50-600 \mathrm{mg} / \mathrm{L}, \mathrm{pH}_{\mathrm{o}}=6.5$ )

\subsection{Adsorption Kinetic Study}

In the present study Pseudo first, second order models, modified Freundlich and Elovich models were applied to determine the kinetic study of adsorption of 4-nitroaniline on to BFA. For all adsorbate-adsorbent system, the significant parametric effect to determine kinetics, based on initial concentration was made.

The pseudo-first order kinetic equation is given as:

$\log \left(\mathrm{q}_{\mathrm{e}}-\mathrm{q}_{\mathrm{t}}\right)=\log \mathrm{q}_{\mathrm{t}}-\frac{\mathrm{k}_{\mathrm{f}}}{2.303} \mathrm{t}$

Wherek $\mathrm{f}_{\mathrm{f}}\left(\mathrm{min}^{-1}\right)$ is the first order rate constant, $\mathrm{q}_{\mathrm{e}}$ is the amount of 4-nitroaniline adsorbed on the adsorbent at equilibrium $(\mathrm{mg} / \mathrm{g})$, and $\mathrm{q}_{\mathrm{t}}$ the amount adsorbed on the adsorbent at any time $t$ (mg/g) [24]. These constants can be calculated from the slope and intercept of the plot $\ln \left(\mathrm{q}_{\mathrm{e}}-\mathrm{q}_{\mathrm{t}}\right)$ versus time $t$.

The pseudo-second-order model is given as:

$\mathrm{q}_{\mathrm{t}}=\frac{\mathrm{k}_{\mathrm{s}} \mathrm{q}_{\mathrm{e}}^{2} \mathrm{t}}{1+\mathrm{k}_{\mathrm{s}} \mathrm{q}_{\mathrm{e}} \mathrm{t}}$
Where $\mathrm{k}_{\mathrm{S}}$ is the rate constant $(\mathrm{g} / \mathrm{mg}$. $\mathrm{min}), \mathrm{q}_{\mathrm{t}}$ the amount adsorbed on the adsorbent at any time $t$ $(\mathrm{mg} / \mathrm{g}), \mathrm{q}_{\mathrm{e}}$ is the amount of 4-nitroaniline adsorbed on the adsorbent at equilibrium $(\mathrm{mg} / \mathrm{g})$. The constants can be determined by the plot of $t / q_{t}$ versus $\mathrm{t}$ [25].

The linear form of modified Freundlich model is given as [26]

$\ln \mathrm{q}_{\mathrm{t}}=\ln \left(\mathrm{kc}_{\mathrm{o}}\right)+\frac{1}{\mathrm{~m}} \ln \mathrm{t}$

Where, $\mathrm{q}_{\mathrm{t}}(\mathrm{mg} / \mathrm{g})=$ amount adsorbed at any time $t, k$ $(\mathrm{L} / \mathrm{g} \min )=$ adsorption rate constant, $\mathrm{C}_{0}(\mathrm{mg} / \mathrm{L})=$ initial concentration, $t(\mathrm{~min})=$ contact time and $\mathrm{m}=$ constant (Kuo - Lotse). A graph of $\ln \left(\mathrm{q}_{\mathrm{t}}\right) \mathrm{v} / \mathrm{s} \ln (\mathrm{t})$ is plotted.

The Elovich equation is given as follows $[27,28]$

$\mathrm{q}_{\mathrm{t}}=\frac{1}{\beta} \ln (\mathrm{a} \beta)+\frac{1}{\beta} \ln \mathrm{t}$

Where, $\mathrm{a}(\mathrm{mg} / \mathrm{g} \mathrm{min})=$ initial rate, $\beta(\mathrm{g} / \mathrm{mg})=$ parameter that relates surface coverage and energy of activation during chemical adsorption [29]. A graph of $\ln (\mathrm{t}) \mathrm{v} / \mathrm{s} q_{t}$, is plotted. For all the models the constants, regression coefficients were determined and tabulated in Table1. Pseudo second order model shows that $q_{e, \text { Expt }}$ and $q_{e, \text { Cacl }}$ are close to one another. Linear regression coefficients values are unity and less for pseudo first order, modified Freundlich and Elovich models. Therefore, adsorption kinetics is better suited for pseudo second order model for adsorption of 4-nitroaniline onto BFA as compared to other models.

\subsection{Desorption Study}

Adsorbate-loaded BFA was stirred with $100 \mathrm{ml}$ of various solvents and the results are shown in Figure 7. A very low desorption was observed for 4-nitroaniline with the mineral acids (Nitric, Hydrochloric and sulphuric acid), alkali (sodium hydroxide) organic acid (acetic acid) and water compared with desorption percent obtained with acetone and ethyl alcohol. The 4-nitroanilinedesorption from 4-nitroaniline loaded BFA which shows that only $36 \%$ and $27 \%$ of 4-nitroaniline could be recovered, using acetone and ethyl alcohol solvents respectively. A very low desorption of 4-nitroaniline indicates that some complex formation takes place between the active sites of bagasse fly ash and the 4-nitroaniline [20]. 
Table 1: Kinetic Parameters for Sorption of 4-nitroaniline by BFA

\begin{tabular}{|c|c|c|c|c|c|c|}
\hline \multirow{3}{*}{ Kinetic Models/Constants } & \multicolumn{6}{|c|}{ BFA-4-nitroaniline } \\
\hline & \multicolumn{6}{|c|}{ Concentration (mg/L) } \\
\hline & 50 & 100 & 150 & 200 & 250 & 300 \\
\hline \multicolumn{7}{|l|}{ Pseudo First Order } \\
\hline $\mathrm{q}_{\text {eCalc }}(\mathrm{mg} / \mathrm{g})$ & 1.138 & 3.673 & 5.272 & 3.342 & 3.573 & 4.989 \\
\hline $\mathrm{K}_{\mathrm{f}}\left(\min ^{-1}\right)$ & -0.071 & -0.046 & -0.055 & -0.032 & -0.028 & -0.037 \\
\hline$\overline{\mathrm{R}^{2}}$ & 0.950 & 0.989 & 0.996 & 0.988 & 0.954 & 0.930 \\
\hline \multicolumn{7}{|l|}{ Pseudo Second Order } \\
\hline qeCalc (mg/g) & 4.950 & 9.009 & 11.765 & 12.987 & 13.333 & 12.658 \\
\hline $\mathrm{q}_{\mathrm{exppt}}(\mathrm{mg} / \mathrm{g})$ & 4.900 & 8.800 & 11.460 & 12.800 & 13.000 & 12.300 \\
\hline $\mathrm{h}(\mathrm{mg} / \mathrm{g} \min )$ & 3.436 & 3.106 & 4.219 & 5.650 & 4.950 & 3.401 \\
\hline $\mathrm{K}_{\mathrm{s}}(\mathrm{g} / \mathrm{mg} \min )$ & 0.140 & 0.038 & 0.030 & 0.033 & 0.028 & 0.021 \\
\hline $\mathrm{R}^{2}$ & 0.999 & 0.999 & 0.999 & 0.999 & 0.999 & 0.999 \\
\hline \multicolumn{7}{|c|}{ Modified Freundlich Equation } \\
\hline$\sqrt{3}$ & 15.385 & 7.874 & 7.874 & 13.699 & 11.905 & 8.696 \\
\hline $\mathrm{k}(\mathrm{L} / \mathrm{g})$ & 0.072 & 0.049 & 0.042 & 0.045 & 0.035 & 0.024 \\
\hline $\mathrm{R}^{2}$ & 0.920 & 0.937 & 0.934 & 0.979 & 0.980 & 0.945 \\
\hline Elovich Equation & & & & & & 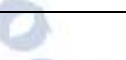 \\
\hline$\beta(\mathrm{g} / \mathrm{mg})$ & 0.301 & 0.936 & 1.233 & 0.842 & 0.958 & 1.175 \\
\hline $\mathrm{a}(\mathrm{mg} / \mathrm{g} \min )$ & -0.099 & -0.012 & -0.002 & 0.000 & 0.000 & -0.001 \\
\hline $\mathrm{R}^{2}$ & 0.939 & 0.957 & 0.950 & 0.978 & 0.983 & 0.972 \\
\hline
\end{tabular}
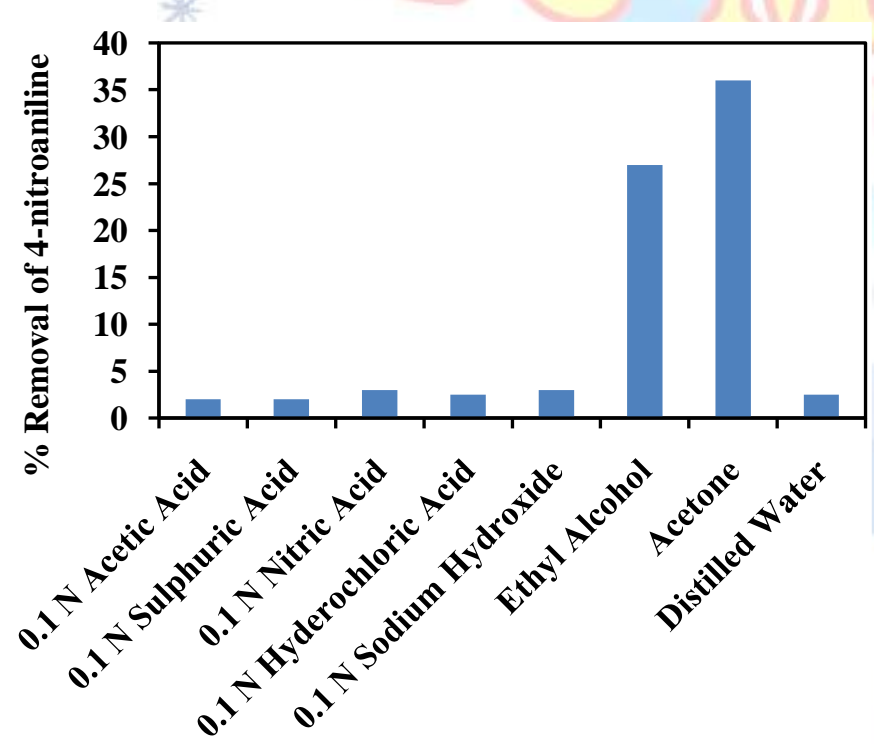

Figure 7: Desorption of 4-nitroaniline by Various Solvents from Loaded BFA

\section{CONCLUSIONS}

The present study shows that 4-nitroaniline can be treated using bagasse fly ash (BFA) as an effective adsorbent from aqueous solutions. The maximum removal of 4-nitroaniline was observed up to $98 \%$ in the lower concentration range $(50$ $\mathrm{mg} / \mathrm{L}$ ) and $40 \%$ in the higher concentration range (300 mg/L) using a BFA dose of $10 \mathrm{~g} / \mathrm{L}$ at normal temperature. Equilibrium contact time for adsorbate was found to be $3 \mathrm{~h}$ for all the concentrations. Optimum removal of 4-nitroaniline occurred at respective natural $\mathrm{pH} 6.5$ and Optimum adsorbent dosage was found to be $10 \mathrm{~g} / \mathrm{L}$. Adsorption was observed to be very fast and 80\% 4-nitroaniline removal was achieved within initial 30 minutes of contact between BFA $(\mathrm{m}=10 \mathrm{~g} / \mathrm{L})$ and the 4-nitroaniline solution $\left(C_{0}=50-300 \mathrm{mg} / \mathrm{L}\right)$ at 303K. The 4-nitroaniline adsorption was found to follow the pseudo-second-order kinetics.4-Nitroaniline loaded BFA regeneration was found to be very less with distilled water, alkali, mineral and organic acids. The maximum desorption efficiency shown by acetone $(36 \%)$ and ethyl alcohol $(27 \%)$ for 4-nitroaniline and BFA system.

\section{REFERENCES}

[1] Guangqian Wu, Guannan Wu, Qisheng Zhang, Adsorptive removal of p-nitroaniline from aqueous solution by bamboo, Desalination and Water Treatment, 57 (2016) 26448-26460

[2] Khalid, M. Arshad, and D. E. Crowley, Biodegradation potential of pure and mixed bacterial cultures for removal of 4- nitroaniline from textile dye wastewater, Water Research, 43 (4), 2009, 1110-1116. 
[3] R. S. Nair, C. S. Auletta, R. E. Schroeder, and F. R. Johannsen, Chronic toxicity, oncogenic potential, and reproductive toxicity of p-nitroaniline in rats, Fundamental and Applied Toxicology, 15(3), 1990, 607-621.

[4] G. Wang, X. Zhang, C. Yao, and M. Tian, Four-week oral toxicity study of three metabolites of nitrobenzene in rats, Drug and Chemical Toxicology, 33(3), 2010, 238-243.

[5] Mehmet A. Oturan, Jose Peiroten, Pascal Chartrin, and Aurel J. Acher, Complete Destruction of p-Nitrophenol in Aqueous Medium by Electro-Fenton Method, Environ. Sci. Technol., 34 (16), 2000, 3474-3479.

[6] J.-H. Sun, S.P. Sun, M.H. Fan, H. Q. Guo, L.P. Qiao, and R. $\mathrm{X}$. Sun, A kinetic study on the degradation of p-nitroaniline by Fenton oxidation process, Journal of Hazardous Materials, 148(1-2), 2007,172-177.

[7] H.J. Ma, M. Wang, C.Y. Pu, J. Zhang, S. Zhao, S. Yao, J. Xiong, Transient and steady-state photolysis of p-nitroaniline in aqueous solution, J. Hazard. Mater. 165, 2009, 867-873.

[8] W.M. Wu, S.J. Liang, Y. Chen, L.J. Shen, H.R. Zheng, L. Wu, High efficient photocatalytic reduction of 4-nitroaniline to p-phenylenediamine over microcrystalline $\mathrm{SrBi}_{2} \mathrm{Nb}_{2} \mathrm{O}_{9}$, Catal. Commun., 17, 201, 2012, 39-42.

[9] A. Qureshi, V. Verma, A. Kapley, H.J. Purohit, Degradation of 4-nitroaniline by Stenotrophomonas strain HPC 135, Int. Biodeterior. Biodegrad. 60, 2007, 215-218.

[10] J.H. Sun, S.P. Sun, M.H. Fan, H.Q. Guo, Y.F. Lee, R.X. Sun, Oxidative decomposition of p-nitroaniline in water by solar photo-Fenton advanced oxidation process, J. Hazard. Mater. 153, 2008, 187-193.

[11] K.Q. Li, Z. Zheng, J.W. Feng, J. Zhang, X. Luo, G. Zhao, X.F. Huang, Adsorption of p-nitroaniline from aqueous solutions ontoactivated carbon fiber prepared from cotton stalk, J. Hazard. Mater. 166, 2009, 1180-1185.

[12] J.H. Huang, X.G. Wang, K.L. Huang, Adsorption of p-nitroaniline by phenolic hydroxyl groups modified hyper-cross-linked polymeric adsorbent and XAD-4: A comparative study, Chem. Eng. J. 155, 2009, 722-727.

[13] K. Zheng, B.C. Pan, Q.J. Zhang, W.M. Zhang, Enhanced adsorption of p-nitroaniline from water by a carboxylated polymeric adsorbent, Sep. Purif. Technol. 57, 2007, 250-256.

[14] C.H. Geng, R.M. Cheng, X.C. Xu, Y.W. Chen, Adsorption of 4-nitroaniline and $\mathrm{N}, \mathrm{N}$-dimethylaniline on carbon nanotubes, J. East China Normal Univ. 5-6, 2008, 138-142.

[15] Praveen Kumar D.G, Kalleshappa C.M and Aravinda H.B, Fixed-Bed column studies on adsorption of 4-nitroaniline from aqueous solution by bagasse fly ash,International Journal of Engineering Science Invention (IJESI),7 (9) VerII, 2018, 39-46.

[16] Praveen Kumar D G, Kalleshappa C. M., Aravinda H.B., Removal of nitrobenzene from aqueous solution by adsorption on bagasse fly ash, International Journal of Modern Trends in Engineering and Research, 5 (8), 2018, 20-27.

[17] D.H. Lataye, I.M. Mishra, I.D. Mall, Removal of pyridine from aqueous solution by adsorption on bagasse fly ash, Indus. Eng.Chem. Res. 45(1), 2006, 3934-3943.

[18] I.D. Mall, S. Tewari, N. Singh, I.M. Mishra, Utilisation of bagasse fly ash and carbon waste from fertiliser plant for treatment of pyridine and 3-picoline bearing wastewater, in: Proceeding of the 18th International Conference on Solid Waste Technology and Management Held at Philadelphia, PA, USA, March 23-26, 2003.

[19] V.C. Srivastava, M.M. Swamy, I.D. Mall, B. Prasad, I.M. Mishra, Adsorptive removal of phenol by bagasse fly ash and activated carbon: equilibrium, kinetics and thermodynamics, Colloids Surf. A: Physicochem. Eng. Aspects 272, 2005, 89-104.

[20] MeghaSyamRauthula, Vimal Chandra Srivastava, "Studies on adsorption/ desorption of nitrobenzene and humic acid onto/from activated carbon", Chemical Engineering Journal, 168, 2011, 35-43.

[21] Mall I.D., Srivastava V.C., Agarwal N.K., Mishra I.M., "Adsorptive removal of malachite green dye from aqueous solution by bagasse fly ash and activated carbon-kinetic study and equilibrium isotherm analyses". Colloid Surface A., 264, 2005 a, 17-28.

[22] Praveen Kumar D.G, Kalleshappa C.M and Aravinda H.B, Adsorption of Picric Acid onto Granular Activated Carbon from Aqueous Solution: Parametric, Kinetic, Equilibrium and Thermodynamic Study, International Journal of Latest Engineering and Management Research (IJLEMR), 3(8) 2018. 19-29

[23] Tien C., Adsorption Calculations and Modeling, Butterworth-Heinemann, 1994.

[24] V.C. Srivastava, I.D. Mall, I.M. Mishra, "Adsorption of toxic metal ions onto activated carbon. Study of sorption behavior through characterization and kinetics", Chem. Eng. Process. 47, 2008, 1269-1280.

[25] Y.S. Ho, M.G. Kay, "Pseudo-second order model for sorption processes", Process Biochem. 34, 1999, 451-465.

[26] Kuo S., Lotse E. G., "Kinetics of phosphate adsorption and desorption by hematite and gibbsite", Soil Sci. Soc. Am. J., 116, 1973, 400-406.

[27] Cheung C.W., Porter J.F., McKay G., "Sorption kinetics for the removal of copper and zinc from effluents using bone char", Sep. and Purif. Technol., 19, 2000, 55-64.

[28] Onal Y., "Kinetics of adsorption of dyes from aqueous solution using activated carbon prepared from waste apricot”, J. Hazard. Mater.,B137, 2006, 1719-1728.

[29] Teng Hsisheng, and Chien- Hsieh, Liquid-phase adsorption of phenol by activated carbons prepared from bituminous coals with different oxygen contents, Journal of Chemical Technology and biotechnology, 74(2), 1999, 123-130. 